\title{
Process Simulation of Biodiesel Production from Jatropha Curcas Seed Oil
}

\author{
Aldo Okullo*, Noah Tibasiima \\ Department of Chemistry, Kyambogo University, Kampala, Uganda \\ Email address: \\ okulloapita@yahoo.com (A. Okullo),ntibasiima@gmail.com (N. Tibasiima) \\ ${ }^{*}$ Corresponding author \\ To cite this article: \\ Aldo Okullo, Noah Tibasiima. Process Simulation of Biodiesel Production from Jatropha Curcas Seed Oil. American Journal of Chemical \\ Engineering. Vol. 5, No. 4, 2017, pp. 56-63. doi: 10.11648/j.ajche.20170504.12
}

Received: April 14, 2017; Accepted: May 12, 2017; Published: July 4, 2017

\begin{abstract}
The increasing concerns over diminishing fossil fuel supplies and rising oil prices, as well as adverse environmental and human health impacts from the use of such fuels have led to the need of finding alternative fuels that will reduce the dependency on fossil fuels. Biodiesel from plant and animal oils sources, has been identified as such an alternative fuel. However, the major obstacle in the production and commercialization of biodiesel is the production cost. This high cost is mainly attributed to the cost of using edible vegetable oil as feedstock. There is a need to obtain biodiesel without compromising food security. In this paper, an alkali catalyzed continuous transesterification process with a capacity of 8000 tonnes/year of biodiesel from jatropha curcas seed oil was designed and simulated in HYSYS. Laboratory data was used for the simulation and the process was able to produce biodiesel of high purity (over 99.65\%) and by-product glycerine with the purity grade of $95.3 \%$.
\end{abstract}

Keywords: Process Simulation, HYSYS, Biodiesel, Jatropha Curcas, Triolein

\section{Introduction}

The concerns that fossil fuel sources are diminishing, coupled with environmental degradation have increased the pace of research to try and identify alternative sources of fuel because it is widely recognised that renewable and nonconventional sources of energy for transportation could play a key role in energy generation and consumption patterns in the future. In search of such alternatives, the potential utilization of plant and animal oils or fats as substitutes for diesel fuels known as biodiesel has received significant attention all over the world. The demand for biodiesel increased more recently as a result of price increases for petroleum fuel products [1] and also due to biodiesel's merit of reduced net carbon dioxide emissions by $78 \%$ on a lifecycle basis when compared to conventional diesel fuel [2]. Plant and animal oils are structurally similar to the long chain hydrocarbons which are found in diesel oils. They are environmentally friendly but need to be evaluated on a caseby-case basis for their potential [3-4].

Most existing biodiesel production plants rely on the use of edible vegetable oils derived from soybean, rapeseed (canola), palm and coconut [5]. Unfortunately the high cost of biodiesel production is the key barrier to its large-scale commercialization [6-7], the cost being attributed to using edible vegetable oil as feedstock. The use of food sources to produce energy has also caused widespread concern to the credibility of this new technology thus initiating an exploration for techniques to reduce the production cost of biodiesel, especially the cost of the feedstock, in much recent research.

The application of non-edible vegetable oils from plant species like jatropha curcas has been advocated for by many researchers [4, 8, 9-10]. Jatropha curcas is considered the most suitable species for biodiesel production because it meets all the European Union standard requirements and above all, for its drought resistance ability induced by CDNA (JCPIP2) gene found in this species [11]

According to [8] several government bodies, international organisations, national bodies and NGOs are promoting the 
use of jatropha curcas and other oil bearing plants for economic and environmental sustainability.

There are two main objectives of these initiatives; (i) to use plant oils and their derivatives for economic and environmental sustainability in rural development and (ii) to make rural areas self-sufficient in energy especially energy from liquid fuels. This is to be achieved, where possible, without displacing other agricultural crops or competing for land that has a higher opportunity in other applications.

Many organisations such as the World Bank, International Plant Genetic Research Institute, Austrian and German Technical Assistance Programmes, the Rockefeller Foundation, Appropriate Technology and Plant Oil Producers Association of Zimbabwe formulated various goals for these purpose which can be summarised as:

1) To promote the use of plant oil as a fuel in stationary or mobile engines for water pumping, grain milling, transportation and electricity generation;

2) To encourage the use of plant oil as a viable renewable energy option for cooking, lighting and heating;

3) To reduce poverty, especially for women, by encouraging economic activities in rural areas through the use of such plant oils for the manufacture of soap, medicines, lubricants, chemicals, fertilizers, insecticides;

4) To improve the environment through land reclamation, erosion control, enhanced soil fertility, produce a better microclimate and Green House Gas (GHG) mitigation;

On successful implementation of these goals they should lead to improved quality of life for the rural community; a reduction in consumption of firewood in the rural areas; an increase in gross domestic product (GDP); a reduction of expenditure on imported fuels for rural consumption; a decrease in deforestation rate; a more productive land use; an expanded options for carbon dioxide abatement; the establishment of decentralized technology chains based on the use of plant oil; and promotion of South-based new technology development.

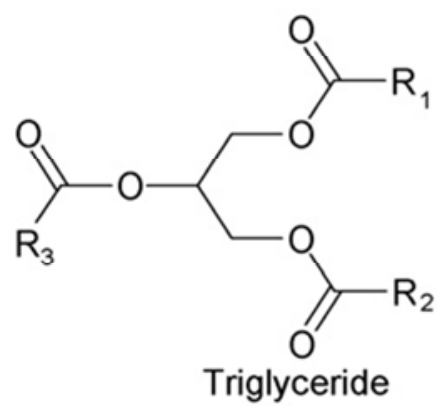

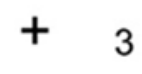

Methanol<smiles>[R]C(=O)OC</smiles><smiles>[R2]C(=O)OC</smiles><smiles>OCC(O)CO</smiles>

Glycerol

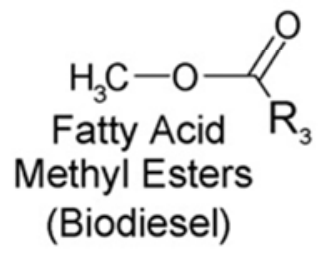

Figure 1. Transesterification reaction equation of triglyceride and methanol.

Among several methods for producing biodiesel are pyrolysis, microemulsification, and transesterification. Transesterification involves the reaction of the plant or animal oil with an alcohol. The reaction can be catalysed by bases, acids [12], enzymes [13-14] or carried out under supercritical conditions in the absence of a catalyst [15-16]. The alcohol used is of low molecular weight with ethanol having most consideration due to its low cost [17] and it is obtainable from biomass. However, greater conversions into biodiesel can be reached using methanol as it is less sensitive to water in the alkali catalysed process than ethanol.

Commercial production of biodiesel from plant oils is mainly by alkali catalysed transesterification where a chemical reaction involving the plant oil and alcohol yields fatty acid alkyl esters (biodiesel) and glycerol (by-product) in the presence of a base catalyst such as sodium hydroxide as shown in Figure 1. The glycerol by-product is typically about 50\% pure and contains excess alcohol and catalyst [18-20].

Due to the impurities, the glycerol by-product must generally be refined before commercial use in other industrial sectors $[21,22]$.

Many process simulation models have emerged in recent researches to assess the technical and economic feasibility of biodiesel production plant configurations. These models have been developed by using different flowsheet simulators such as Aspen Plus, Aspen HYSYS and SuperPro Designer. Reference [6] proposed a two-step process in which the esterification of high free fatty acids (FFAs) feedstock is carried out using an acid catalyst in the first step followed by an alkali catalysed transesterification of the treated oil. On the other hand, [23] proposed four different configurations using HYSYS to study the production routes using virgin vegetable oils and waste cooking oils (WCO) under alkali and acid catalysis. The authors concluded that all the processes proved to be feasible for producing a high quality biodiesel product under reasonable operating conditions with the alkali process having the simplest configuration. However, [24] further concluded that the WCO acid-catalysed was the most cost effective. Meanwhile [7] simulated four 
continuous processes using HYSYS and waste vegetable oils alone under homogenous and heterogeneous catalysis, they concluded that the heterogeneous acid catalyst process was more beneficial. Reference [25] presented a process for obtaining biodiesel from low-grade animal fats. Other simulation studies that have been carried out have utilized solid resin-catalyzed transesterification [26], enzyme catalysis [27-28] and supercritical conditions [29-31].

Most of these simulation models have shown that the continuous heterogeneously acid-catalysed transesterification process has the lowest manufacturing costs. However, acid catalysts generally have a weak catalytic activity and require high reaction temperatures and long reaction times, compared with base catalysts.

This paper gives a simulation for biodiesel production process from jatropha curcas seed oil using alkali catalysed transesterification. However, from literature, data on the kinetics of transesterification of jatropha oil are varied. In addition, fatty acid compositions vary from plant to plant and depend on geographical location, altitude and other environmental factors [32]. Several researchers report various mechanisms and kinetics of transesterification [3337]. Some of these kinetics are first orders, some are pseudo first orders and others are second orders for the same reaction of vegetable oils. These various kinetics and mechanisms do not give us clear design methods to follow and because of this, modelling reactors as conversion reactors rather than the traditional kinetics method becomes important and it was used in this study.

\section{Methods and Materials}

The physical-chemical characterization of the refined Jatropha curcas seed oil considered in this work was carried out in a previous study by the corresponding author [11] and results from the study formed the composition basis for this work.

\subsection{Process Simulation}

Albeit some differences do exist between results obtained from process simulation and real plant process operation, modern simulation software, if effectively used, can provide dependable information on process operation due to their comprehensive thermodynamic packages, advanced calculation techniques and vast component libraries. As such Hyprotech System (HYSYS) V8 was used in this work to conduct the simulation. The procedure followed for the simulation process, based on use of HYSYS simulator, is shown of Figure 2.

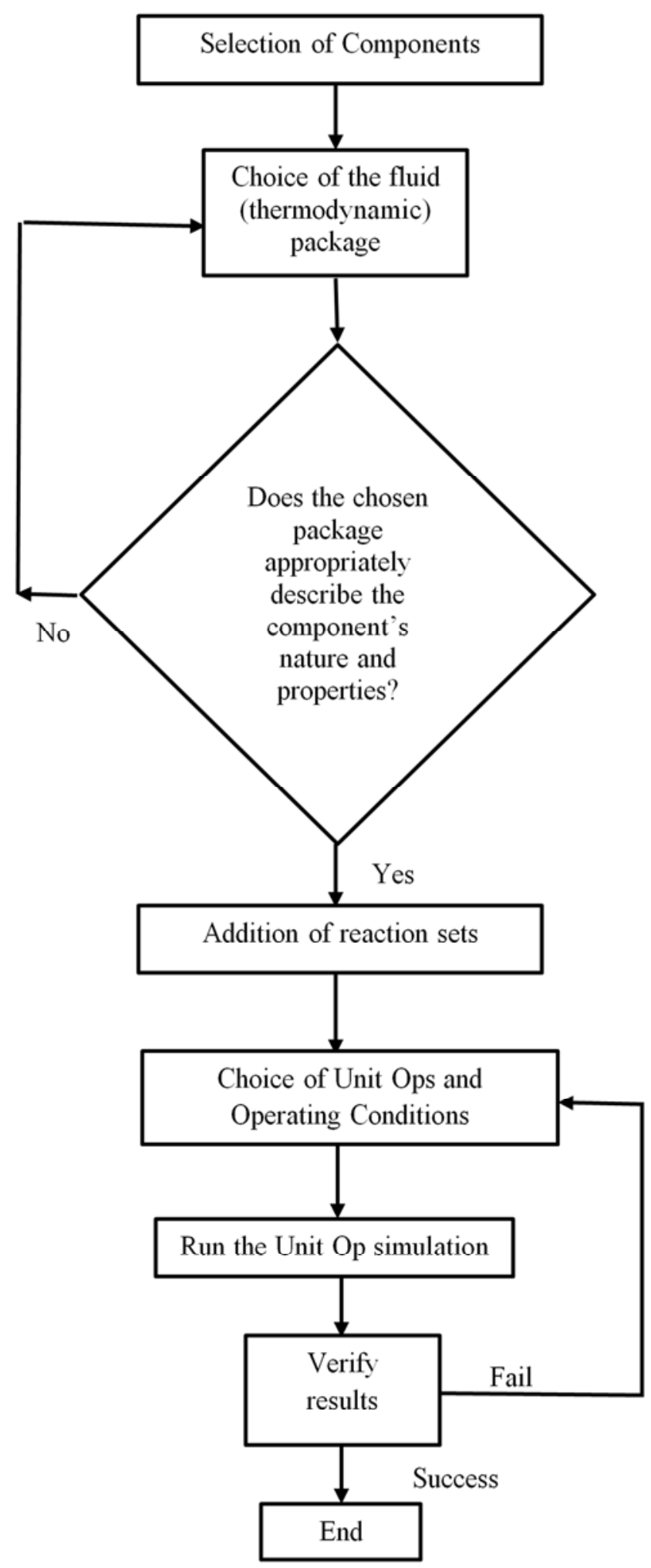

Figure 2. Schematic representation of the simulation process.

\subsection{Chemical Components}

The basic components required for the simulation of the process such as methanol, sodium hydroxide, water, and glycerol were readily available in HYSYS' component database. Since Oleic acid is the major fatty acid in Jatropha oil (J-Oil) [38], triolein was chosen to represent J-Oil in the 
simulation and methyl oleate, which is available in the HYSYS component library, was taken as the product of the transesterification reaction. Components not available in the traditional HYSYS library were specified using the "Hypo Manager" tool. Phosphoric acid, sodium phosphate and triolein were all defined following detailed procedures by [39-40] and the estimated properties compared with the DIPPR thermo-physical databank for verification. Specification of a component required input of a number of properties, such as normal boiling point, density, molecular weight, as well as the critical properties of the substance.

\subsection{Thermodynamic Model}

Due to the presence of polar compounds (methanol and glycerol) in the process, the non-random two liquid (NRTL) thermodynamic model was selected for use as the property package for calculation of activity coefficient of the liquid phase in the simulation following the decision algorithm outlined by [41]. The unavailable binary interaction parameters in the simulation databank were estimated using the UNIFAC vapour-liquid equilibrium and UNIFAC liquidliquid equilibrium methods.

\subsection{Plant Capacity, Unit Operations and Operating Conditions}

Plant capacity was specified at 8000 metric tonnes/year biodiesel, similar to the continuous biodiesel plant capacity described by [23, 42]. This translated to about $1000 \mathrm{~kg} / \mathrm{h}$ of jatropha oil feed. The alcohol was specified to excess $(6: 1$ alcohol to oil molar ratio) in order to shift the reaction equilibrium to the products end. The process unit operations included reactors, distillation columns, extraction column, pumps, separators and heat exchangers.

Because detailed information from literature on the kinetics of the alkali catalysed transesterification of J-Oil were varying, the transesterification reactor was modelled as a simple conversion reactor model with $98.86 \%$ conversion of triglyceride to jatropha methyl-ester (JME) [11] with main units operating conditions set as those described by [39, 43-44].

Some assumptions considered in this work are outlined below:

1) The transesterification reactor is a perfectly mixed flow (continuous stirred tank reactor)

2) Laboratory scale reaction conditions and conversion data [11] available were assumed to be appropriate for large-scale production, and set as the operating conditions for the reactor
3) Anhydrous alcohol, anhydrous catalyst and refined JOil with less than $0.5 \mathrm{wt} \%$ free fatty acids are used.

4) Constant input of J-Oil feed throughout the year with 8000 working hours for a production of 8000 tonnes/year biodiesel.

5) Feed is $100 \%$ solid particle free.

6) The theoretical reaction intermediates such as diglycerides and monoglycerides are neglected.

Multi-stage distillation was used to recover the excess methanol, as well as in the final purification of biodiesel and glycerine products since the large difference in the boiling points of the components facilitates distillation [23]. The distillation columns were specified to meet or exceed the ASTM D 6751 standard for biodiesel purity (99.65 wt. \%) and operated under vacuum as it was imperative to keep the methyl-ester and glycerine purification columns temperatures of the distillate and bottoms streams at suitably low levels, since biodiesel and glycerol are subject to degradation at temperatures greater than $250^{\circ} \mathrm{C}$ and $150^{\circ} \mathrm{C}$, respectively [45-46].

Since high content of glycerine in the biodiesel can lead to storage problems due to phase separation, clogging of the injector fuel and emission of aldehydes present in the combustion gases of biodiesel [47], the methyl-ester needs to be separated from the glycerol, methanol and catalyst. The separation process is based on the facts that fatty acid, alcohol esters and glycerol are sparingly mutually soluble, and that there is a significant difference in density between the ester and glycerol phases. The presence of methanol in one or both phases affects the solubility of ester in glycerol and glycerol in ester.

Some literature have proposed the separation of biodiesel and glycerine by washing the mixture with water [7, 43] or by gravity settling [7, 26, 40, 48]. However [23] indicated that satisfactory separation could not be achieved by gravity alone. In this work the ester/glycerol separation was effected in a washing column $[23,42]$. Warm water $\left(48^{\circ} \mathrm{C}\right.$ to $\left.60^{\circ} \mathrm{C}\right)$ was used as it prevents precipitation of saturated fatty acid esters and retards the formation of emulsions [49].

\section{Results and Discussions}

The simulated continuous process flow sheet is presented below in Figure 3. The process scheme can be described commencing with biodiesel synthesis and followed by the downstream processing steps to obtain pure biodiesel and glycerol products.

Table 1. Main Stream results of the simulated process and fraction compositions.

\begin{tabular}{|c|c|c|c|c|c|c|c|c|}
\hline Stream Name & 1B & $2 D$ & 3 & 5 & 10 & Water & Biodiesel & Glycerol \\
\hline Temperature $\left({ }^{\circ} \mathrm{C}\right)$ & 65.000 & 26.700 & 65.000 & 116.200 & 60.000 & 50.000 & 235.000 & 129.700 \\
\hline Pressure (kPA) & 446.000 & 446.000 & 446.000 & 30.000 & 110.000 & 100.000 & 5.000 & 30.000 \\
\hline Mole flow $(\mathrm{kmol} / \mathrm{h})$ & 1.190 & 7.360 & 8.540 & 5.070 & 12.720 & 11.100 & 3.390 & 1.470 \\
\hline Mass flow $(\mathrm{kg} / \mathrm{h})$ & 1050.000 & 237.700 & 1288.000 & 1177.000 & 329.800 & 200.000 & 1005.000 & 113.000 \\
\hline Methanol & 0.000 & 0.958 & 0.090 & 0.004 & 0.012 & 0.000 & 0.000 & 0.000 \\
\hline Jatropha Oil & 1.000 & 0.000 & 0.011 & 0.013 & 0.000 & 0.000 & 0.000 & 0.000 \\
\hline
\end{tabular}




\begin{tabular}{lllllllll}
\hline Stream Name & 1B & 2D & 3 & 5 & 10 & Water & Biodiesel & Glycerol \\
\hline Glycerol & 0.000 & 0.000 & 0.084 & 0.920 & 0.327 & 0.000 & 0.000 & 0.953 \\
$\mathrm{NaOH}$ & 0.000 & 0.042 & 0.008 & 0.009 & 0.000 & 0.000 & 0.000 \\
$\mathrm{H}_{2} \mathrm{O}$ & 0.000 & 0.000 & 0.000 & 0.000 & 0.620 & 0.000 \\
$\mathrm{H}_{3} \mathrm{PO}_{4}$ & 0.000 & 0.000 & 0.000 & 0.000 & 0.000 & 0.000 & 0.000 \\
$\mathrm{Na}_{3} \mathrm{PO}_{4}$ & 0.000 & 0.000 & 0.000 & 0.000 & 0.041 & 0.000 & 0.000 \\
\hline
\end{tabular}

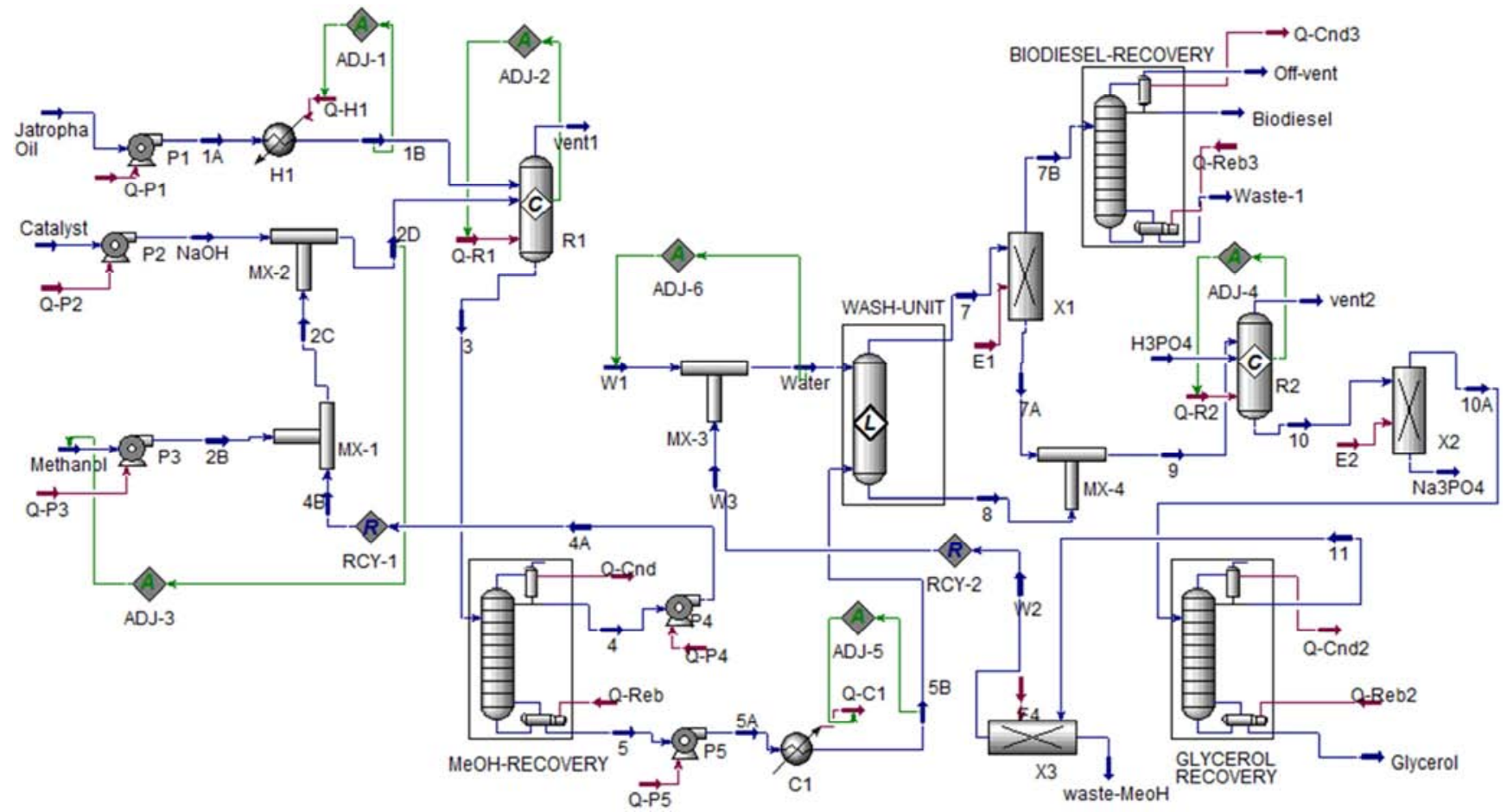

Figure 3. Simulation model flowsheet.

\subsection{Transesterification / Biodiesel Synthesis}

The reaction was carried out with a $6: 1$ molar ratio of methanol to J-Oil, $1 \%$ wt. catalyst (based on oil) at $65^{\circ} \mathrm{C}$ and $446 \mathrm{kPa}$ in reactor $\mathrm{R} 1$.

Fresh Methanol $(116.5 \mathrm{~kg} / \mathrm{h})$ with a composition of $100 \%$ methanol was pumped through P3 and mixed with $111.2 \mathrm{~kg} / \mathrm{h}$ of recycled methanol (stream 4B) from the methanol recovery unit prior to being mixed with $10 \mathrm{~kg} / \mathrm{h}$ of catalyst (sodium hydroxide) then fed to R1 through stream 2D. J-Oil $(1050 \mathrm{~kg} / \mathrm{h})$, with a composition of $100 \%$ triolein was pressurised to $446 \mathrm{kPa}$ through pump $\mathrm{P} 1$ then heated to $65^{\circ} \mathrm{C}$ in $\mathrm{H} 1$ (set by $\mathrm{ADJ}-1$ ) before entering reactor $\mathrm{R} 1$ where it reacted with the mixed feed from stream $2 \mathrm{D}$. In R1, $98.86 \%$ of J-Oil was converted to JME, producing glycerol as byproduct. The temperature of the reactor was maintained at $65^{\circ} \mathrm{C}$ using $\mathrm{ADJ}-2$ with the reaction molar ratio (6:1 methanol to oil) maintained using ADJ-3. Stream 3 containing $80.77 \mathrm{wt} \% \mathrm{JME}, 8.36 \mathrm{wt} \%$ glycerol and unreacted J-Oil, methanol and all catalyst was fed to the methanol recovery unit.

\subsection{Methanol Recovery}

The methanol recovery unit was operated under vacuum with the condenser and re-boiler pressures at $20 \mathrm{kPa}$ and $30 \mathrm{kPa}$ respectively to keep the bottom temperature under $150^{\circ} \mathrm{C}$. The condenser was operated as a total condenser to recover methanol in the liquid phase. A methanol recovery rate of $99.99 \%$ and a methanol component recovery of $100 \%$ in stream 4 (column top) were used as specifications for the column. The number of stages of this unit was defined basing on the amount and quality of methanol recovered. Columns using more than three stages and reflux ratios greater than two showed the same methanol recovery thus five theoretical stages and an initial estimate for the reflux ratio was taken as 1.5 , however the column converged quickly at a reflux ratio of 2 which was then chosen. Stream 4 (at $28.6^{\circ} \mathrm{C}$ ) was pressurised through $\mathrm{P} 4$ and recycled through stream 4B which is mixed with fresh methanol and re-fed to the reactor. The bottom stream 5 (at $116.2^{\circ} \mathrm{C}$ ) containing $88.4 \% \mathrm{JME}$, $0.9 \%$ catalyst, $0.4 \%$ methanol, $9.2 \%$ glycerol and traces of unreacted $\mathrm{J}$-Oil is pressurised to $200 \mathrm{kPa}$ then cooled in $\mathrm{C} 1$ to $65^{\circ} \mathrm{C}$ (set by ADJ-5) and sent to the washing unit.

\subsection{JME $\mid$ Glycerol Separation}

Initially this operation was conducted isothermally using a decanter and an initial water sensitivity analysis was carried out to ascertain the amount of water that can influence the separation as well as allowing for recycling. For this mode of operation, an increase in the water supplied to the process led to a decrease in the separation effect due to the existence of a 
homogeneous region thus the biodiesel, glycerol and water exited in a single stream. However on carrying out the operation adiabatically, the separation effect was found independent of the amount of water used and the glycerol was effectively drawn out of the ester phase.

The washing unit was modelled as a liquid-liquid extraction process. Water at $50^{\circ} \mathrm{C}(200 \mathrm{~kg} / \mathrm{h})$ was added to the wash unit. This pulls the glycerol out of the ester phase. At $60^{\circ} \mathrm{C}$ and $110 \mathrm{kPa}$, stream 7 contained $98.6 \mathrm{wt} \% \mathrm{JME}$ and no glycerol. The content of other compounds such as the unreacted J-Oil, methanol and water in stream 7 were all in trace amounts less than $2 \%$. All of the glycerol remained in stream $8(321.6 \mathrm{~kg} / \mathrm{h})$ whose composition was $62.2 \%$ water, $33.5 \%$ glycerol, $3 \%$ sodium hydroxide, $1.3 \%$ methanol.

\subsection{JME Purification}

Stream 7B was fed to the biodiesel recovery unit, a column using a reflux ratio of 2 , four theoretical stages and operated under vacuum. The condenser was specified as a partial condenser to ease separation of the JME from water and methanol in the column overhead. A final biodiesel product surpassing ASTM D 6751 specifications (greater than 99.65 wt $\%$ ) was obtained.

The water and methanol were as vent gases (off-vent) and a $1004 \mathrm{~kg} / \mathrm{h}$ pure JME product $(100 \%)$ was obtained as biodiesel (at $235^{\circ} \mathrm{C}$ ). The bottom stream of this unit contained $14.7 \mathrm{~kg} / \mathrm{h}$ of unconverted J-Oil which was treated as waste.

\subsection{Catalyst Neutralization}

The catalyst in stream 7 was removed via component splitter $\mathrm{X} 1$ and stream 7A mixed with stream 8 . At a flow rate of $321.6 \mathrm{~kg} / \mathrm{h}$, stream $9\left(60^{\circ} \mathrm{C}\right)$ was charged to reactor $\mathrm{R} 2$ operated at $60^{\circ} \mathrm{C}$ (set by $\mathrm{ADJ}-4$ ) and modelled as a conversion reactor, to neutralise sodium hydroxide (catalyst) by adding pure phosphoric acid (100\%). The resulting sodium phosphate was removed using centrifuge X2. Stream $10 \mathrm{~A}$ contained $64.6 \%$ water, $34.1 \%$ glycerol and $1.3 \%$ methanol. This stream was fed to the glycerol recovery unit.

\subsection{Glycerol Recovery}

Stream 10A was fed to a glycerol recovery column operated under vacuum to keep the temperature levels of glycerol below $150^{\circ} \mathrm{C}$. The column was simulated with 10 theoretical stages and a reflux ratio of 2 . The condenser was specified as a total condenser. At $58^{\circ} \mathrm{C}$ and $20 \mathrm{kPa}$, water and methanol $(203.1 \mathrm{~kg} / \mathrm{h})$ were removed as distillate through stream 11. Methanol was purged off and the remaining water cooled and recycled to the water-washing unit. The glycerol obtained in the bottoms was $95.3 \%$ pure.

\section{Conclusion}

An alkali-catalyzed continuous process for biodiesel production from jatropha curcas seed oil has been simulated for a plant capacity of 8000 tonnes/year. Under the specified conditions and unit operations, the simulated process proved to be feasible for producing a high quality biodiesel product (JME) at high purity exceeding EU 14214/ASTM D 6751 $(>99.65 \%)$ and a glycerol by-product of $95.3 \%$ purity. The unconverted J-Oil was negligible (only 1.4\%) and as such was taken as a waste.

\section{Recommendations}

1) Other purification methods such as dry washing with Magnesium Silicate powder, use of ionic liquids or Deep Eutectic Solvents should be tried on the methyl esters of these oils to assess their viability on an industrial scale.

2) Further research is recommended to use the kinetic parameters for designing the transesterification reactor with explicit material balance equations where economic evaluation of the whole process is carried out.

3) Other methods of transesterification could be tried and assessed for their feasibility in biodiesel production from jatropha oil

\section{Acknowledgement}

The authors greatly acknowledge the support from Deputy Vice Chancellor, Finance and Administration of Kyambogo University for financial support to enable us produce and ultimately publish this paper.

\section{References}

[1] G. Knothe, "Dependence of Biodiesel fuel properties on the structure of fatty acid alkyl esters," Fuel Processng Technology, vol. 10, no. 86, pp. 1059-1070, 2005.

[2] K. S. Tyson, "Biodiesel: Handling and Use Guidelines," Golden, 2001.

[3] Bajpai and Tyagi, "Biodiesel: Source, Production, Composition, Properties and Its Benefits," Journal of Oleo Science, vol. 10, no. 55, pp. 487-502, 2006.

[4] A. K. Agarwal, "Biofuels (Alcohol and biodiesel) applications as fuels for internal combustion engines," Progress in Energy and Combustion Science, no. 33, pp. 233-271, 2007.

[5] G. Knothe, "Analytical methods used in the production and fuel Quality Assessment of Biodiesel," Transaction of the American Society of Agricultural Engineers, vol. 2, no. 44, pp. 193-200, 2001.

[6] M. Canacki and J. Van Gerpen, "Biodiesel production from oils and fats with high free fatty acids," Transactions of the American Society of Agricultural Engineers (ASAE), no. 44, pp. 1429-1436, 2001.

[7] A. H. West, D. Posarac, and N Ellis, "Assessment of four biodiesel production processes using HYSYS. Plant," Bioresource Technology, no. 99, 2008.

[8] K. Openshaw, "A review of Jatropha Curcas L.: An oil plant of unfulfilled promise," Biomass and Bioenergy, no. 19, pp. 115,2000 . 
[9] H. P. S. Makkar and K. Becker, "Jatropha Curcas L.: A potential source for tomorrow's Oil and Biodiesel," Lipid Technology, no. 20, pp. 104-107, 2008.

[10] A. King, J, Cuevas, F. Mark, H. Wei, and A. G. Ian, "Potential of Jatropha Curcas L. as a source of renewable oil and animal feed," Journal of Experimental Botany, no. 60, pp. 2897-2905, 2009.

[11] Aldo Okullo, "Investigating parameters that influence the transesterification reaction kinetics of Jatropha Curcas L. and castor beans oils in biodiesel production," Department of Chemical and Mining Engineering, University of Dar es Salaam, PhD Thesis 2014.

[12] P. M. Ejikeme et al., "Catalysis in Biodiesel Production by Transesterification Processes-An Insight," E-Journal of Chemistry, vol. 7, no. 4, pp. 1120-1132, 2010.

[13] T. T. B. Lan and P. N. Hoa, "Lipase Catalysis for Transesterification Produces Biodiesel Using Coconut Oil as Main Raw Material Source," Biological and Chemical Research, pp. 258-267, 2015.

[14] M. Tuter, C. Akdere, C. Yerlikaya, and A. Sirkecioğlu, "The Evaluation of Fusel Oil Fraction for Lipase Catalyzed Alcoholysis of Hazelnut Oil," Energy Sources, Part A: Recovery, Utilization, and Environmental Effects, pp. 521-528, 2011.

[15] A. Demirbas, "Biodiesel from vegetable oils via transesterification in supercritical methanol," Energy Conversion and Management, pp. 2349-2356, 2002.

[16] S. Saka and D. Kusdiana, "Biodiesel fuel from rapeseed oil as prepared in supercritical methanol," Fuel, no. 80, pp. 225-231, 2001.

[17] A. Dermirbas, "Production of biodiesel fuels from linseed oil using methanol and ethanol in non-catalytic SCF conditions," Biomass and Bioenergy, no. 33, pp. 113-118, 2009.

[18] I. C. Andrade, E. A. Moreno, J. F. S. Cantor, C. A. G. Fajardo, and J. R. Sodré, "Purification of glycerol from biodiesel production by sequential extraction monitored by $1 \mathrm{H}$ NMR," Fuel Processing Technology, vol. 132, pp. 99-104, 2015.

[19] M. R, Nanda, Z. Yuan, W, Qin, M. A. Poirier, and X. Chunbao, "Purification of Crude Glycerol using Acidification: Effects of Acid Types and Product Characterization," Austin Journal of Chemical Engineering, 2014.

[20] Y. Xiao, G. Xiao, and A. Varma, "A Universal Procedure for Crude Glycerol Purification from Different Feedstocks in Biodiesel Production: Experimental and Simulation Study," Industrial \& Engineering Chemistry Research, vol. 52, no. 39, pp. 14291-14296, 2013.

[21] N. Saifuddin, H. Refal, and P. Kumaran, "Rapid Purification of Glycerol by-product from Biodiesel Production through Combined Process of Microwave Assisted Acidification and Adsorption via Chitosan Immobilized with Yeast," Research Journal of Applied Sciences, Engineering and Technology, vol. 7, no. 3, pp. 593-602, 2014.

[22] T. Surrod and C. Pattamaprom, "Purification of Glycerin Byproduct from Biodiesel Production Using Electrolysis Process," in The Second TSME International Conference on Mechanical Engineering, Krabi, Thailand, 2011.

[23] Y. Zhang, M. A. Dube, D. D. Mclean, and M. Kates, "Biodiesel production from waste cooking oil: 1. Process design and technological assessment," Bioresource Technology, pp. 1-16, 2003.

[24] Y Zhang, M. A. Dube, D. D. Mclean, and M. Kates, "Biodiesel production from waste cooking oil: 2. Economic Assesment and Sensitivity analysis.," Bioresource Technology, pp. 229-240, 2003.

[25] L. Canoira, M. R. Gamero, E. Querol, R. Alcantara, M. Lapuerta and F. olivia, "Biodiesel from low-grade animal fat: production process assessment and biodiesel properties characterization," Industrial \& Engineering Chemistry Research, pp. 7997-8004, 2008.

[26] J. Marchetti, V. Miguel, and A. Errazu, "Techno-economic study of different alternatives for biodiesel production," Fuel Processing Technology, pp. 740-748, 2008.

[27] K. G. Harding, J. S. Dennis, H. von Blottnitz, and S. T. L Harrison, "A life-cycle comparison between inorganic and biological catalysis for the production of biodiesel," Joural of Cleaner Production, pp. 1368-1378, 2007.

[28] L. F. Sotoft, B. Rong, K. V. Christensen, and B. Norddahl, "Process Simulation and economic evaluation of enzymatic biodiesel production plant," Bioresesource Technology, pp. 5266-5274, 2010.

[29] Y. Lim, H. Lee, and C. Han, "Design and economic analysis of the process for biodiesel fuel production from transesterificated rapeseed oil using supercritical methanol," Industrial \& Engineering Chemistry Research, pp. 5370-5378, 2009.

[30] S. Lee, D. Posarac, and N. Ellis, "Process simulation and economic analysis of biodiesel production processes using fresh and waste vegetable oil.," Chemical Engineering Research and Design, pp. 2626-2642, 2011.

[31] S. Morias, T. M. Mata, A. A. Martins, G. A. Pinto, and C. A. V. Costa, "Simulation and life cycle assessment of process design alternatives for biodiesel production from waste vegetable oils," Journal of Cleaner Production, pp. 1251-1259, 2010.

[32] A. Okullo, A. K. Temu, and J. W. Ntalikwa, "Transesterification Reaction Kinetics of Jatropha Oil for Biodiesel Production," Second International Conference on Advances in Engineering and Technology, pp. 221-227, 2011.

[33] H. Noureddini and D. Zhu, "Kinetics of Transesterification of Soybean Oil," Journal of American Oil Chemical Society, pp. 1457-1463, 1997.

[34] D. Darnoko and C. Munir, "Kinetics of Palm Oil Transesterification in a Batch Reactor," Journal of American Oil Chemical Society, pp. 1263-1267, 2000.

[35] Theerayut Leevijit, Worawut Wisutmethangoon, Gumpon Prateepchaikul, Charktir Tongurai, and Michael Allen, "Transesterification of Palm Oil in Series of Continuous Stirred Tank Reactor," Asian Journal of Energy and Environment, pp. 336-346, 2006.

[36] Vicente Gemma, Martinez Mercedes, and Aracil Jose, "Kinetics of Brassica carinata Oil Methanolysis," Energy and Fuels, pp. 1722-1726, 2006.

[37] Manolito E. Jr. Bambase, Nakamura Nobuyuki, Tanaka Junko, and Matsumura Masatoshi, "Kinetics of hydroxide-catalyzed methanolysis of crude sunflower oil for the production of fuel grade mthyl-esters," Journal of Chemical Technology and Biotechnology, pp. 273-280, 2007. 
[38] A. Okullo, A. K. Temu, J. W. Ntalikwa, and P. Ogwok, "Optimization of Biodiesel Production from Jatropha Oil," International Journal of Engineering Research in Africa, pp. 62-73, 2010.

[39] Eric C. Carlson, "Don't Gamble with Physical properties for simulations," Chemical Engineering Progress, pp. 35-46, 1996.

[40] J. Connemann and J. Fischer, "Biodiesel in Europe 1998: Biodiesel processing technologies," in International Liquid Biofuels Congress, Brazil, 1998.

[41] Y. Zhang, "Design and economic assessment of biodiesel production from waste cooking oil," Department of Chemical Engineering, University of Ottawa, M. A. Sc Thesis 2002.

[42] M. J. Haas, A. J. McAloon, W. C. Yee, and T. A. Foglia, "A Process model to estimate biodiesel production costs," Bioresource Technology, pp. 671-678, 2006.

[43] Debalina Sengupta, "Integrating Bioprocesses Into Industrial Complexes For Sustainable Development," Department of
Chemical Engineering, Louisiana State University and Agricultural and Mechanical College, PhD Thesis 2010.

[44] J. W Goodrum, "Volatility and boiling points of biodiesel from vegetable oils and tallow," Biomass \& Bioenergy, pp. 205-211, 2002.

[45] A. A. Newman, Glycerol. Cleveland: CRC Press, 1968.

[46] M. Mittelbatch, "Diesel Fuel Derived from Vegetable Oils, VI: Specifications and Quality Control of Biodiesel," Bioresource Technology, pp. 7-11, 1996.

[47] T. Krawczyk, "Biodiesel," INFORM, pp. 801-822, 1996.

[48] M. Canacki and J Van Gerpen, "A pilot plant to produce biodiesel from high free fatty acid feedstocks," Transactions of the American Society of Agricultural Engineers (ASAE), pp. 945-954, 2003.

[49] F. Karaosmanoglu, K. B. Cigizoglu, M. Tuter, and S. Ertekin, "Investigation of the refining step of biodiesel production," Energy Fuels, pp. 890-895, 1996. 